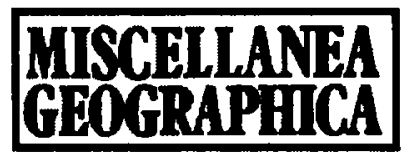

WARSZAWA 2000 Vol. 9

Jerzy Boryczka, Maria Stopa-Boryczka

\title{
THE WARMINGS AND COOLINGS OF THE CLIMATE OF WARSAW DURING THE LAST CENTURIES AND THEIR CONDITIONING
}

The purpose of the work reported was to determine the range of fluctuations and the trend of change in the climate of Warsaw in the $18^{\text {th }}-20^{\text {th }}$ centuries. Another purpose of the work was constituted by the elaboration of the climate change forecast for the city in the $21^{\text {st }}$ century.

The general features of periodicity of climate in Warsaw with reference to other towns of Europe have been presented in the earlier publications originating from the Department of Climatology of the University of Warsaw (Boryczka, 1993, 1998, Boryczka, Stopa-Boryczka et al., 1998, 1999a, b).

The study to date of the long term measurement series showed that in Warsaw, similarly as in other towns of Poland (Cracow, 1826-1990, Wrocław, 1851-1980), or in other European cities (Prague, 1771-1980, Geneva, 1768-1980, Zurich, 1864-1980, Potsdam, 1893-1992), several air temperature cycles of significant amplitudes appear. These cycles have the periods of $3-5,7-8,10-13,73-113$ years, and the planetary cycle of 178.9 years. Their presence in almost all chronological series (of monthly and seasonal values) and the synchronicity of oscillations (close dates of extreme values), primarily for the cycles of about $8,10-13$ and 180 years, indicate that this periodicity is a property of the air temperature field in Europe and in Poland. The results of inquiry into the shorter measurement series of air temperature in Poland, from the years 1951-1990, confirmed this proposition of the cyclical nature of air temperature field in Poland (Żmudzka, 1998).

The secular trends of air temperature (in ${ }^{\circ} \mathrm{C} / 100$ years), determined according to linear trends, are positive in almost all months. This is an evidence for a progressing warming of climate in towns of Europe (and Poland). Increasingly warm are especially winters: in Warsaw by $1.15^{\circ} \mathrm{C} / 100$ years, in Cracow - by $1.72^{\circ} \mathrm{C} / 100$ years, in Prague - by $0.44^{\circ} \mathrm{C} / 100$ years, or in Geneva - by $0.74^{\circ} \mathrm{C} / 100$ years.

The secular trends of air temperature in the summer season are in some towns positive and in some other - negative. Thus, air temperatures in July are increasingly warmer in, for instance, Warsaw, by $0.19^{\circ} \mathrm{C} / 100$ years, in 
Cracow - by $0.34^{\circ} \mathrm{C} / 100$ years, or in Potsdam - by $0.64^{\circ} \mathrm{C} / 100$ years. On the other hand, the month of July is getting colder in Wrockaw - by $0.73^{\circ} \mathrm{C} / 100$ years, in Prague - by $0.16^{\circ} \mathrm{C} / 100$ years, in Zurich - by $1.08^{\circ} \mathrm{C} / 100$ years, and in Geneva - by $0.08^{\circ} \mathrm{C} / 100$ years.

The identified periods and trends of air temperature have an enormous importance not only in cognitive, but also in practical terms. They make it possible to forecast the natural component of climate changes in Europe (and in Poland), and to separate the anthropological component. By extrapolating the values of the function of temporal air temperature trends (beyond the time interval of measurements) the forecasts of trends of climate change were elaborated for the $21^{\text {st }}$ century for Warsaw and for other places in Europe. These forecasts are quite unique against the background of both Polish and international literature in the domain. The forecasts known to date (the "2 $\times \mathrm{CO}_{2}$ scenario") concern only the anthropological component. They neglect the natural changes of climate, caused by the fluctuations of the solar constant and the changes in volcanic activity, observed in the preindustrial period and nowadays.

Reliable insights into future are obtained, reaching beyond the year 2100 , founded upon the superposition of cycles of air temperature, synchronous with the cycles of the solar constant, conditioned by the variability of the parameters of the solar system. The forecasts indicate the natural cooling of climate in the $21^{\text {st }}$ century. It can be expected that the natural cycles of climate observed nowadays and earlier (in Holocene) will be repeated in the future and will shape the climate of the Earth in the centuries to come.

The coldest winters, with average temperatures of $-7^{\circ} \mathrm{C}$, will take place in the middle of the next century at about the year 2050. They will be slightly milder than the winters of the beginning of the $19^{\text {th }}$ century, in view of the increasing trend in the anthropological component. On the other hand, the cooler summers will take place sooner, in the first two decades of the $21^{\text {st }}$ century.

THE ESSENTIAL WARMINGS AND COOLINGS OF THE CLIMATE IN WARSAW IN THE YEARS 1966-1995 AND 1779-1990

The primary evidence for the warming of the climate of Warsaw in the last years is constituted by the positive differences of the average values of air temperature from the years 1966-1995 and 1779-1979:

\begin{tabular}{|l|r|r|r|r|r|r|r|c|c|c|c|c|c|}
\hline & \multicolumn{1}{c|}{ I } & \multicolumn{1}{c|}{ II } & \multicolumn{1}{c|}{ III } & \multicolumn{1}{c|}{ IV } & \multicolumn{1}{c|}{ V } & VI & VII & VIII & IX & X & XI & XII & I-XII \\
\hline $1966-1995$ & -2.6 & -1.6 & 2.5 & 7.7 & 13.6 & 16.5 & 18.2 & 17.6 & 13.1 & 8.2 & 3.0 & -0.6 & 8.0 \\
$1779-1979$ & -4.2 & -2.9 & 1.7 & 7.3 & 13.4 & 17.0 & 18.6 & 17.7 & 13.5 & 7.9 & 2.1 & -2.0 & 7.5 \\
$\Delta T$ & 1.6 & 1.3 & 0.8 & 0.4 & 0.2 & -0.5 & -0.4 & -0.1 & -0.4 & 0.3 & 0.9 & 1.4 & 0.5 \\
\hline
\end{tabular}

It is interesting to note that the differences of air temperature, $\Delta T$, be- 
tween the recent 30-year period and the last two centuries are positive in winter $\left(\Delta T\right.$ for January $\left.=1.6^{\circ} \mathrm{C}\right)$, while in the summer, including September, they are negative $\left(\Delta T\right.$ for June $\left.=-0.5^{\circ} \mathrm{C}\right)$. Thus, the average temperature of January in the recent years increased by as much as $1.6^{\circ} \mathrm{C}$ in comparison with the average for the period 1779-1979. On the other hand, June is getting cooler - on the average by $0.5^{\circ} \mathrm{C}$ in comparison with the years 1779-1979.

Thus, we can state that the winters in the years 1966-1995 are significantly warmer than in the period of two centuries of 1779-1979, while summers are cooler.

The variability of the air temperature (extreme - maximum and minimum - values of daily averages, and their dates) is illustrated for the period analysed (1966-1995 and 1779-1990) in the table below:

\begin{tabular}{|r|r|r|r|r|r|r|r|r|r|r|}
\hline \multirow{2}{*}{ Months } & \multicolumn{4}{|c|}{ Extreme values (1966-1995) } & \multicolumn{4}{c|}{ Extreme values (1779-1990) } \\
\cline { 2 - 10 } & Max & Date & Min & Date & $\Delta T$ & Max & Date & Min & Date & $\Delta T$ \\
\hline I & 3.2 & 1983 & -12.3 & 1987 & 15.5 & 3.6 & 1983 & -16.9 & 1803 & 20.5 \\
II & 4.7 & 1990 & -9.6 & 1986 & 14.3 & 5.1 & 1990 & -13.9 & 1929 & 19.0 \\
III & 6.6 & 1990 & -2.2 & 1987 & 8.8 & 7.5 & 1836 & -6.9 & 1845 & 14.4 \\
IV & 9.5 & 1968 & 5.6 & 1982 & 3.9 & 13.6 & 1918 & 2.6 & 1817 & 11.0 \\
V & 16.5 & 1993 & 9.9 & 1980 & 6.6 & 18.7 & 1801 & 7.9 & 1864 & 10.8 \\
VI & 19.8 & 1979 & 14.4 & 1984 & 5.4 & 22.7 & 1811 & 13.0 & 1923 & 9.7 \\
VII & 22.0 & 1994 & 15.0 & 1979 & 7.0 & 22.8 & 1811 & 14.1 & 1832 & 8.7 \\
VIII & 19.5 & 1971 & 15.2 & 1987 & 4.3 & 24.2 & 1807 & 13.4 & 1833 & 10.8 \\
IX & 16.4 & 1967 & 11.2 & 1971 & 5.3 & 16.9 & 1806 & 9.3 & 1797 & 7.6 \\
& & & & 1979 & & & & & 1912 & \\
& & & & 1990 & & & & & 1912 & \\
X & 11.3 & 1967 & 5.7 & 1993 & 5.6 & 13.0 & 1907 & 1.8 & 1805 & 11.2 \\
XI & 5.4 & 1969 & -2.7 & 1993 & 8.1 & 7.6 & 1926 & -3.1 & 1919 & 10.7 \\
XII & 3.1 & 1971 & -8.5 & 1969 & 11.6 & 3.4 & 1971 & -14.3 & 1788 & 17.7 \\
I-XII & 22.0 & 1994 & -12.3 & 1987 & 34.3 & 24.2 & 1807 & -16.9 & 1803 & 41.1 \\
\hline
\end{tabular}

The monthly averages of air temperature in particular years of the thirty years period analysed range between $-12.3^{\circ} \mathrm{C}$ for January 1987 and $22^{\circ} \mathrm{C}$ for July 1994. In the two-century period of 1779-1990 this range was, naturally, significantly bigger: between $-16.9^{\circ} \mathrm{C}$ in January 1803 and $24.2^{\circ} \mathrm{C}$ in August 1807. The difference $\Delta T=\mathrm{Max}-$ Min for particular months has the ranges of, respectively, $3.9^{\circ} \mathrm{C}$ to $15.5^{\circ} \mathrm{C}$ for the period $1966-1995$, and $7.6^{\circ} \mathrm{C}$ to $20.5^{\circ} \mathrm{C}$ for the period $1779-1990$.

In the thirty years period of 1966-1995, analysed here, the average maximum temperature $\left(T_{\max }=12.2^{\circ} \mathrm{C}\right)$ is by $4.2^{\circ} \mathrm{C}$ higher than the annual average $\left(8.0^{\circ} \mathrm{C}\right)$, while the average minimum temperature $\left(T_{\min }=4.1^{\circ} \mathrm{C}\right)$ is lower by $3.9^{\circ} \mathrm{C}$ : 


\begin{tabular}{|l|r|r|r|r|r|c|c|c|r|r|r|r|r|}
\hline & \multicolumn{1}{|c|}{ I } & \multicolumn{1}{c|}{ II } & \multicolumn{1}{c|}{ III } & \multicolumn{1}{c|}{ IV } & \multicolumn{1}{c|}{ V } & VI & VII & VIII & \multicolumn{1}{c|}{ IX } & \multicolumn{1}{|c|}{ X } & XI & XII & Year \\
\hline$T$ & -2.6 & -1.6 & 2.5 & 7.7 & 13.6 & 16.5 & 18.2 & 17.6 & 13.1 & 8.2 & 3.0 & -0.6 & 8.0 \\
$T_{\max }$ & 0.0 & 1.5 & 6.6 & 12.8 & 19.1 & 21.9 & 23.7 & 23.3 & 18.2 & 12.5 & 5.6 & 1.7 & 12.2 \\
$T_{\min }$ & -5.3 & -4.4 & -1.0 & 3.0 & 8.1 & 11.2 & 12.8 & 12.2 & 8.7 & 4.5 & 0.5 & -3.1 & 3.9 \\
\hline
\end{tabular}

Thus, the highest monthly maximum temperature is $T_{\max }=23.7^{\circ} \mathrm{C}$, while the lowest monthly minimum temperature is $T_{\min }=-5.3^{\circ} \mathrm{C}$. The range of fluctuations of air temperature during a year (the long-term average) is defined by their amplitude, i.e. $T_{\max }-T_{\min }=24.0^{\circ} \mathrm{C}$.

The average highest maxima of air temperature $\left(T_{\mathrm{MAX}}\right)$ and the average lowest minima $\left(T_{\mathrm{MIN}}\right)$, calculated for particular years, are shown in the table below:

\begin{tabular}{|l|r|r|r|r|r|r|r|r|r|r|r|r|r|}
\hline & \multicolumn{1}{|c|}{ I } & \multicolumn{1}{c|}{ II } & \multicolumn{1}{c|}{ III } & \multicolumn{1}{c|}{ IV } & \multicolumn{1}{c|}{ V } & \multicolumn{1}{c|}{ VI } & \multicolumn{1}{c|}{ VII } & VIII & \multicolumn{1}{c|}{ IX } & \multicolumn{1}{c|}{ X } & \multicolumn{1}{c|}{ XI } & \multicolumn{1}{|c|}{ XII } & Year \\
\hline$T$ & -2.6 & -1.6 & 2.5 & 7.7 & 13.6 & 16.5 & 18.2 & 17.6 & 13.1 & 8.2 & 3.0 & -0.6 & 8.0 \\
$T_{\max }$ & 7.2 & 8.3 & 16.5 & 22.2 & 26.9 & 29.3 & 30.7 & 30.6 & 26.1 & 21.2 & 12.9 & 8.6 & 20.0 \\
$T_{\min }$ & -15.6 & -14.0 & -8.6 & -3.4 & 1.2 & 5.0 & 8.0 & 6.4 & 1.8 & -3.4 & -7.4 & -12.9 & -3.6 \\
\hline
\end{tabular}

In spite of the fact that these are not the variables of the series (values from individual measurements), the average absolute maxima $T_{\mathrm{MAX}}$ are more strongly correlated with the average values of temperature $(T)$ than the average absolute minima $T_{\mathrm{MIN}}$.

The average differences $T_{\mathrm{MAX}}-\mathrm{T}$ and $T_{\mathrm{MIN}}-T$ in the year amount to, respectively, $12.0^{\circ} \mathrm{C}$ and $4.4^{\circ} \mathrm{C}$.

The highest air temperature in Warsaw during the whole thirty years period of 1966-1995, i.e. $T_{\mathrm{MAX}}=36.4^{\circ} \mathrm{C}$, was observed on August $1^{\text {st }}, 1994$. The lowest air temperature in Warsaw, $T_{\mathrm{MIN}}=-30.7^{\circ} \mathrm{C}$, was measured on January $8^{\text {th }}, 1987$. Thus, the range of temperatures measured was altogether $67.1^{\circ} \mathrm{C}$.

\section{CYCLIC CHANGES OF AIR TEMPERATURE IN WARSAW}

IN THE YEARS 1966-1995 AND 1779-1990

The cyclic fluctuations of air temperature in Warsaw, displaying periodicity longer than one year was usually measured with various methods, and the analysis was restricted to the periods themselves.

It had not been known what was the dispersion of such parameters of the cycles as: periods, amplitudes, and the dates of extreme temperatures for the cycles of the length varying between 1 and 200 years. Further, it had not been known, neither, whether the air temperature cycles are synchronous for Poland and Europe.

Hence, the problem arose of inquiring into the question whether the field of air temperature is uniform with respect to periodicity in various time intervals. 
For this purpose the method of "regression sinusoids" (Boryczka, 1993) was used to determine the parameters of the cycles (periods $\Theta$, amplitudes $b$, and phases $c$ ):

$$
T=a_{0}+b \sin (2 \pi / \Theta+c)
$$

The study of periodicity of air temperature in Warsaw in the years 19661995 accounted not only for the time series of average values also the time series of the extreme air temperature values (daily extremes $-T_{\min }$ and $T_{\text {max }}$, and absolute extremes $-T_{\text {MIN }}$ and $T_{\mathrm{MAX}}$ ).

A high cognitive significance ought to be attached to the comparison of the spectra of oscillations of the average daily air temperature in the range of periods between 0.1 and 30 years, determined on the basis of the 30-year data (1966-1995) and the 210-year data (1779-1990). Additional information on variability of air temperature is contained in the spectra of the extreme values of air temperature in the years 1966-1995.

The cycles identified - their parameters (periods, amplitudes $\Delta T=2 b$, and phases), as well as correlation coefficients $R$, are shown in Table 1 . Individual months and seasons (spring, summer, fall, winter) are treated separately.

In all the chronological series analysed $\left(T, T_{\max }, T_{\min }, T_{\mathrm{MAX}}, T_{\mathrm{MIN}}\right)$ a similar number of cycles exist, among which a part are statistically significant (at the level of significance of 0.05 ). These are usually the following cycles:

\begin{tabular}{|l|l|l|l|l|l|l|l|}
\hline $1966-1995$ & $2.2-1.8$ & $2.9-4.4$ & $5.7-9.2$ & $10.2-11.4$ & $13.8-15.8$ & $17.9-19.9$ & years \\
$1779-1990$ & $2.2-1.6$ & $3.1-4.0$ & $6.5-8.5$ & $10.2-11.2$ & $12.9-15.9$ & $18.0-23.9$ & years \\
\hline
\end{tabular}

An important role in the variability of the climate of Warsaw, especially in winter and in spring, is played by the cycle of about 8-9 years. This periodicity appears in the time series of monthly and seasonal averages of air temperatures of both 210 years and 30 years.

It should be noticed that, for instance, the extremes in the 7.8-year cycle of the winter air temperature values in Warsaw in the years 1966-1995, i.e.

$$
T=-1.46+1.72 \sin (2 \pi t / 7.80+2.180),
$$

coincide with the extremes of solar activity in the 7.8-year cycle and of the similar cycles of the western $(W)$ and eastern $(E)$ zonal circulation:

\begin{tabular}{|l|l|l|l|l|}
\hline Air temperature in Warsaw (1966-1995) & 1964 & 1972 & 1980 & 1987 \\
Solar activity (7.8 year cycle) & 1964 & 1972 & 1980 & 1988 \\
Western zonal circulation $(W)$ & 1965 & 1973 & 1981 & 1988 \\
Eastern zonal circulation $(E)$ & 1965 & 1973 & 1981 & 1988 \\
\hline
\end{tabular}

In winter, the close-to-8-years periodicity of air temperature variability in Warsaw is directly caused by the two macrotypes of zonal circulation western $(W)$ and eastern $(E)$. 


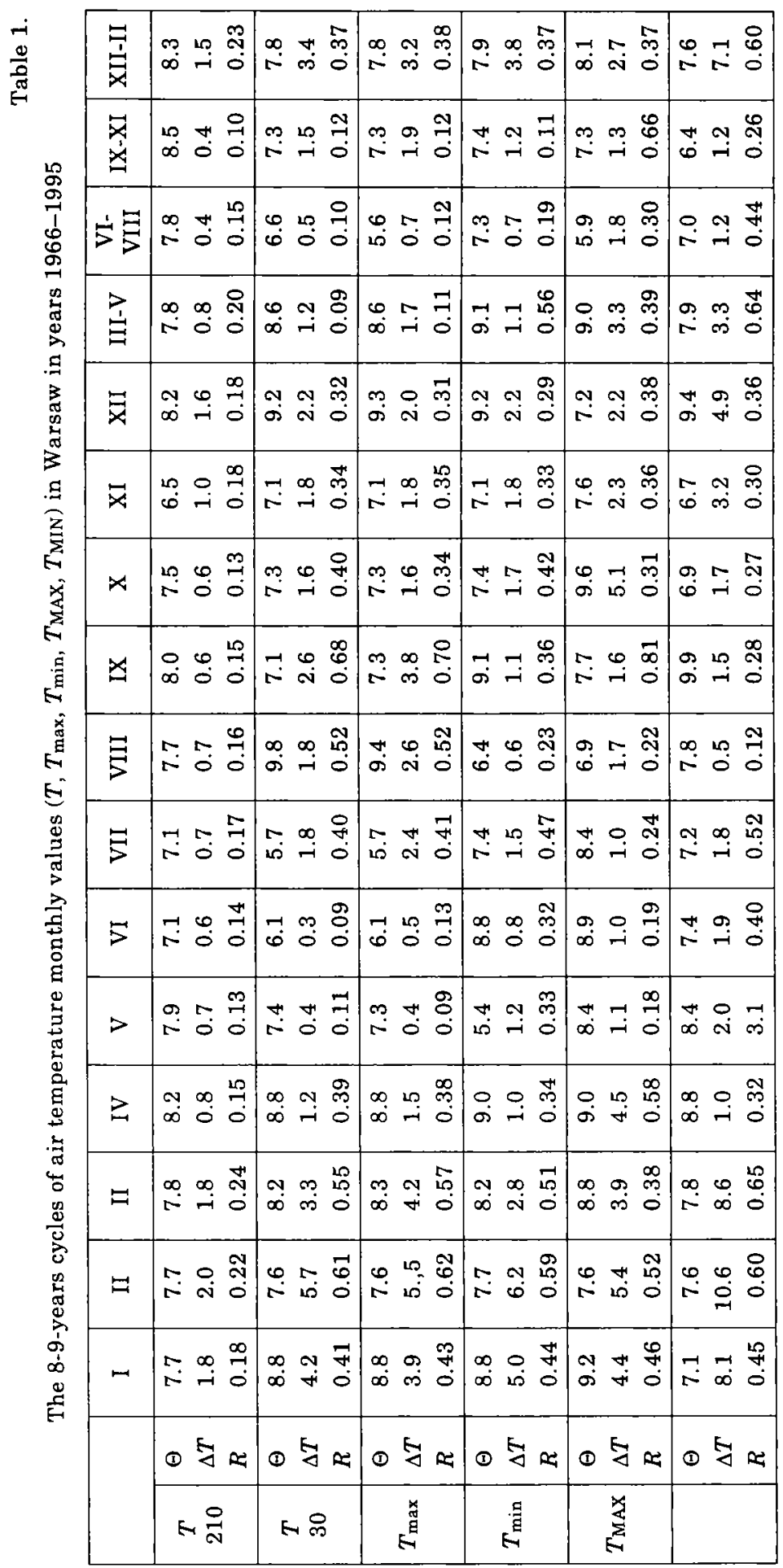


Here are the equations of the "regression sinusoids" for the winter 8-year cycles:

- North Atlantic Oscillation Index (NAO, 1825-1997):

$N A O=0.1315+0.4778 \sin (2 \pi t / 7.80-0.1266), \quad R=0.27$

- Temperature (Warsaw, 1779-1990):

$$
T=2.65+0.75 \sin (2 \pi t / 7.7-0.6870), \quad R=0.23
$$

- Temperature (Wroclaw, 1851-1980):

$$
T=0.719+0.983 \sin (2 \pi t / 7.60+0.4152), \quad R=0.33
$$

- Wolf numbers (1749-1993):

$$
W=51.93+10.40 \sin (2 \pi t / 8.1+2.8659), \quad R=0.17
$$

- Solar acceleration (1749-1980):

$$
S^{\prime}=0.667+1.130 \sin (2 \pi t / 7.80+1.21), \quad R=0.25
$$

The synchronicity of these close to 8 years cycles is demonstrated by the similarity of the dates of the extremes, like the dates of maxima, given here:

\begin{tabular}{|l|l|l|l|l|l|l|l|l|l|l|}
\hline NAO & 1936 & 1944 & 1952 & 1960 & 1967 & 1975 & 1983 & 1991 & 1999 & 2007 \\
Warsaw & 1936 & 1944 & 1951 & 1959 & 1967 & 1974 & 1982 & 1990 & 1997 & 2005 \\
Wrocław & 1936 & 1944 & 1951 & 1959 & 1966 & 1974 & 1982 & 1989 & 1997 & 2004 \\
Wolf numbers & 1934 & 1942 & 1950 & 1958 & 1966 & 1974 & 1982 & 1990 & 1999 & 2007 \\
Solar acceleration & 1934 & 1942 & 1950 & 1958 & 1966 & 1974 & 1981 & 1989 & 1997 & 2005 \\
\hline
\end{tabular}

The probability of a random coincidence of the length of these 8-year winter cycles and of the dates of extremes (minima and maxima) is virtually equal zero. These are the deterministic components of the North Atlantic Oscillation (NAO, after P.D. Jones et al., 1997), conditioning air temperature in Western and Central Europe, and so also in Poland.

\section{TRENDS OF AIR TEMPERATURE IN THE 30-YEAR PERIOD OF 1966-1995 AND THE 210-YEAR PERIOD OF 1779-1990}

The trends of changes in the climate of Warsaw were determined on the basis of time series of the average monthly air temperature values, extreme averages, as well as averages from the absolute maxima and minima, measured at the peripheral weather station of Warsaw-Okęcie.

When making comparisons, use was also made of the long time series of measurement results obtained from the 210-year series of 1779-1990.

The trends of air temperature $(\partial T / \partial t=A)$ are defined by the - straight - regression lines

$$
T=A_{0}+A t
$$

They are characterised by the average increments of air temperature expressed in ${ }^{\circ} \mathrm{C} / 10$ years in the respective intervals of approximation, corresponding to periods 1966-1995 and 1779-1990: 


\begin{tabular}{|c|c|c|c|c|c|c|c|c|c|c|c|c|}
\hline Period & I & II & III & IV & V & VI & VII & VIII & IX & X & \multicolumn{1}{|c|}{ XI } & XII \\
\hline $1966-1995$ & 1.66 & 0.34 & 0.29 & 0.29 & 0.10 & -0.26 & 0.28 & 0.24 & 0.06 & -0.14 & -0.76 & 0.39 \\
$1779-1990$ & 0.12 & 0.05 & 0.10 & 0.08 & 0.04 & 0.03 & 0.02 & -0.00 & 0.02 & 0.06 & 0.11 & 0.14 \\
\hline
\end{tabular}

In spite of the different time intervals one can still draw the conclusion that the progressing warming in winter has been much more pronounced in the last decades of the $20^{\text {th }}$ century than in the last two centuries. The regression coefficients are usually positive $(A>0$, indicating an increase), though in some summer and autumn months they happen to be negative $(A<0$, indicating a decrease).

The inclination $(\operatorname{tg} \alpha=A)$ of the regression lines (see Figs. 1 to 6$)$ represent in the time periods analysed the progressing warming or cooling. Thus, for instance, the air temperature trends in January are increasing in the two time periods considered and amount to $1.7^{\circ} \mathrm{C} / 10$ years in the 30 -year period, and to $0.12^{\circ} \mathrm{C} / 10$ years in the 210 -year period. The rate of increase of air temperature at the end of the $20^{\text {th }}$ century is by more than $1^{\circ} \mathrm{C} / 10$ years bigger than on the average in the period 1779-1990.

The situation is different in the summer and autumn months, during which a cooling is observed especially at the end of this century. Over the last three decades the months of June, September, October and November have been getting cooler. The decreases of air temperature in these months amount, respectively, to: $-0.26 ;-0.06 ;-0.16$; and $-0.76^{\circ} \mathrm{C} / 10$ years. In November the downward temperature trend attains even $-0.8^{\circ} \mathrm{C} / 10$ years.

During the last two centuries (1779-1990) the trend of air temperature in the summer months in Warsaw are for the most part positive and close to zero (statistically insignificant).

Similar trends are observed for the other thermal characteristics (maximum and minimum averages, as well as average absolute maxima and minima):

\begin{tabular}{|l|c|c|c|r|r|r|r|c|r|r|r|c|}
\hline & I & II & III & \multicolumn{1}{c|}{ IV } & \multicolumn{1}{c|}{ V } & \multicolumn{1}{c|}{ VI } & VII & VIII & \multicolumn{1}{|c|}{ IX } & \multicolumn{1}{c|}{ X } & \multicolumn{1}{c|}{ XI } & XII \\
\hline$T$ & 1.66 & 0.34 & 0.29 & 0.29 & 0.10 & -0.26 & 0.28 & 0.24 & -0.06 & -0.14 & -0.76 & 0.39 \\
$T_{\max }$ & 1.57 & 0.41 & 0.34 & 0.36 & 0.24 & 0.28 & 0.43 & 0.35 & 0.33 & 0.02 & 0.71 & 0.37 \\
$T_{\text {MAX }}$ & 2.23 & 0.36 & 0.09 & -0.02 & -0.27 & -0.24 & 0.64 & 1.43 & -0.44 & 0.07 & -0.95 & 1.55 \\
$T_{\min }$ & 1.90 & 0.28 & 0.30 & 2.26 & -0.12 & -0.14 & 0.02 & 0.09 & 0.18 & -0.20 & -0.09 & 0.42 \\
$T_{\text {MIN }}$ & 2.12 & 1.16 & 0.12 & -0.28 & -0.27 & 0.46 & -0.12 & 0.25 & 0.69 & -0.24 & -0.69 & 0.45 \\
\hline
\end{tabular}

The most pronounced increasing trends are displayed by the absolute extremes of air temperature in January, for $T_{\mathrm{MAX}}-2.23^{\circ} \mathrm{C} / 10$ years, and for $T_{\mathrm{MIN}}-2.12^{\circ} \mathrm{C} / 10$ years. The tendencies of temperatures $T_{\mathrm{MAX}}, T_{\mathrm{MIN}}$ in the summer months are usually decreasing. The most important cooling, though, takes place in the autumn months, like $-0.95^{\circ} \mathrm{C} / 10$ years for $T_{\text {MAX }}$ and $-0.69^{\circ} \mathrm{C} / 10$ years for $T_{\text {MIN }}$ in November. It is likewise, interesting to note that in June $T_{\mathrm{MAX}}$ decreases by $0.24^{\circ} \mathrm{C} / 10$ years, while $T_{\mathrm{MIN}}$ increases by $0.46^{\circ} \mathrm{C} / 10$ years.

The increasing and decreasing air temperature trends in Warsaw in the years 1966-1995 and 1779-1990 do not support, but to the contrary - they 

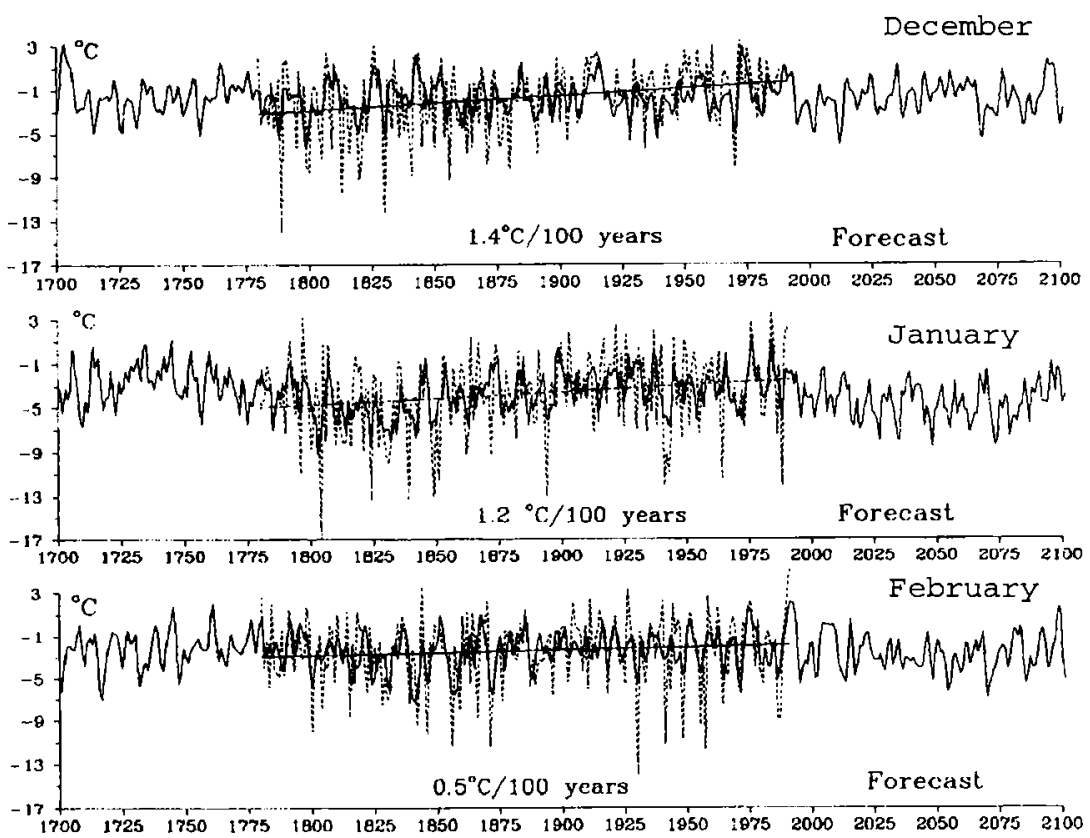

Fig. 1. Air temperature changes in Warsaw: trends and forecasts for the $21^{\text {st }}$ c. - winter (XII, I, II).
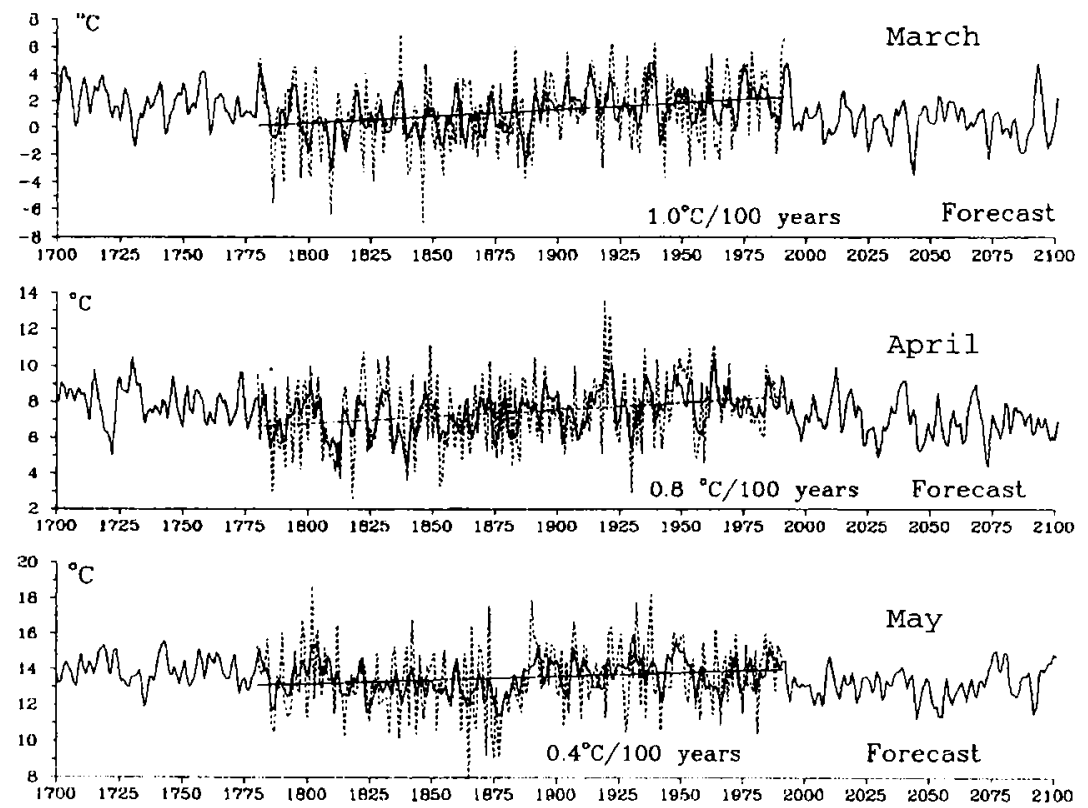

Fig. 2. Air temperature changes in Warsaw: trends and forecasts for the $21^{\text {st }} \mathrm{c}$. - spring (III, IV, V). 

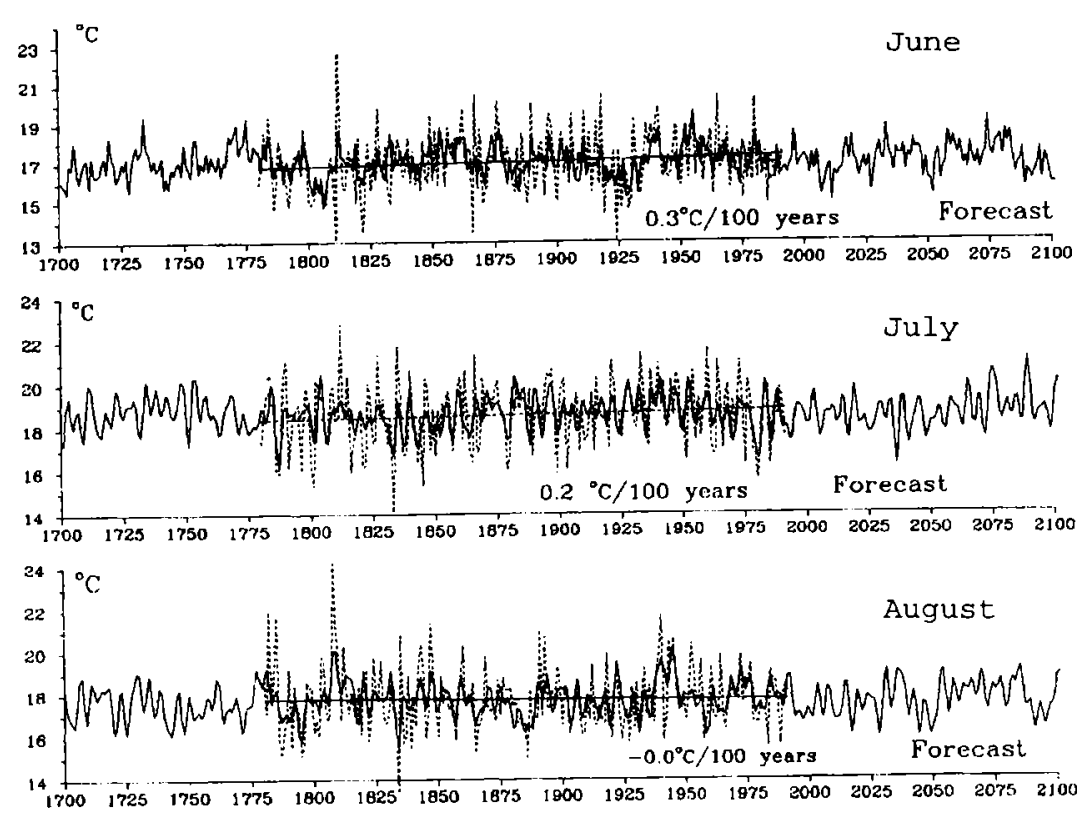

Fig. 3. Air temperature changes in Warsaw: trends and forecasts for the $21^{\text {st }} \mathrm{c}$. - summer (VI, VII, VIII).
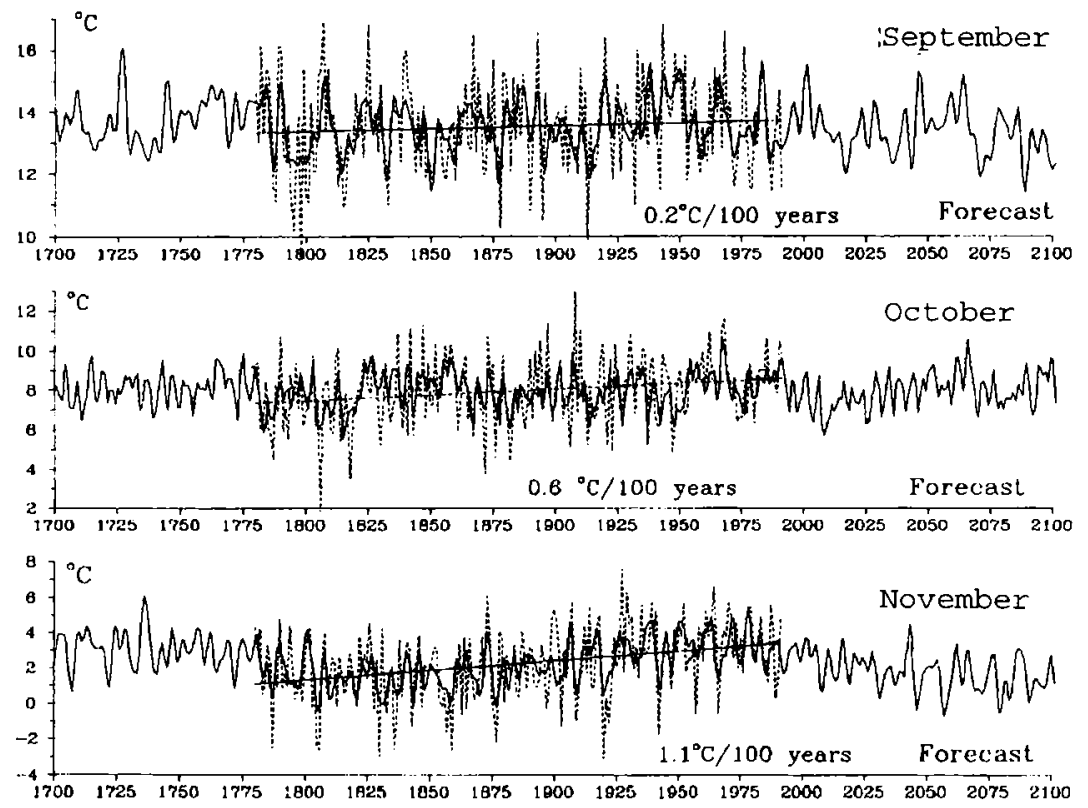

Fig. 4. Air temperature changes in Warsaw: trends and forecasts for the $21^{\text {st }}$ c. - autumn (IX, $\mathrm{X}, \mathrm{XI}$ ). 

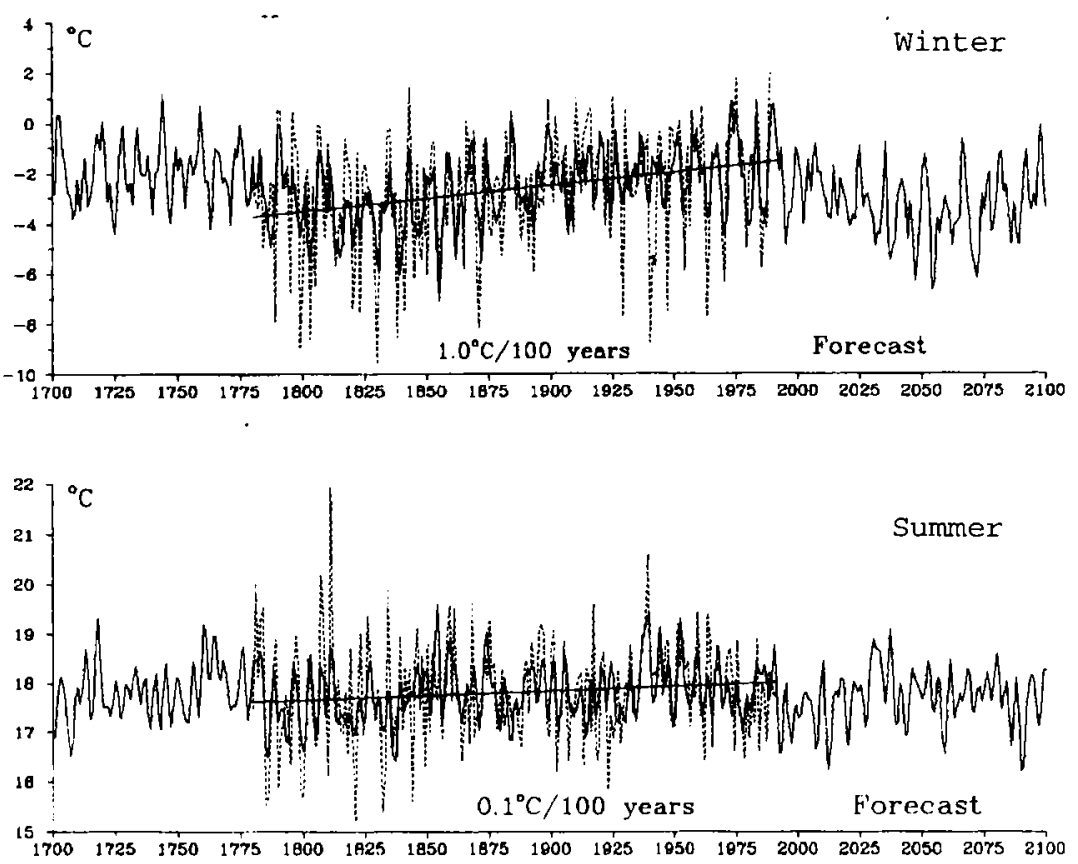

Fig. 5. Air temperature changes in Warsaw: trends and forecasts for the $21^{\text {st }} \mathrm{c}$. - winter (XIIII) and summer (VI-VIII).
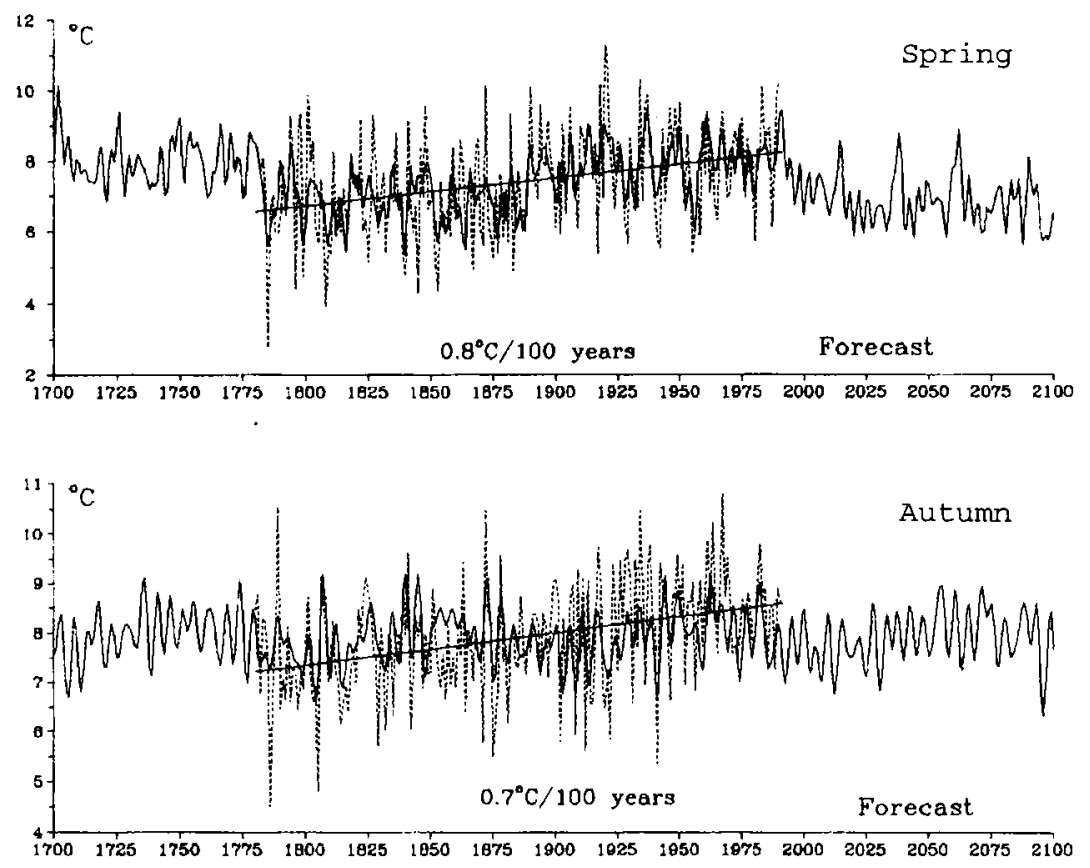

Fig. 6. Air temperature changes in Warsaw: trends and forecasts for the $21^{\text {st }}$ c. - spring (IIIV) and autumn (IX-XI). 
rather seem to contradict - the hypothesis of global climate warming, supposed to result from the greenhouse effect brought about by the increase of the atmospheric content of carbon dioxide and other so-called greenhouse gases. The increasing air temperature trends in winter are probably mainly caused by the changes in the frequency of appearance of the macrotypes of circulation of the air flowing over the territory of Poland.

It is otherwise known that the increasing trends of air temperature during the last two centuries are the result of interference of the natural air temperature cycles within the intervals of approximation.

The quite high values of the regression coefficient $A$ calculated for the winter months may also be brought about by the local factors - the "urban heat island". They may result, as well, from the decreased reflection coefficient and the increasing accumulation of heat by the overbuilt areas (artificial surfaces), especially in winter.

\section{THE FORECAST OF COOLINGS AND WARMINGS OF THE CLIMATE IN WARSAW IN THE $21^{\text {ST }}$ CENTURY}

Assumption was adopted in the forecasts of climate changes for the $21^{\text {st }}$ century that the cycles identified in the measurement series from the $18^{\text {th }}$ $20^{\text {th }}$ centuries will get repeated in the next century. Adoption of this kind of assumption is justified by the presence of identical periods in the spectra of astronomical variables: the solar activity (the solar constant) and the parameters of the solar system.

The reality of the periods identified in the measurement series in Poland and in Europe is also confirmed by the presence of the periods having lengths close to 100 and 200 years in the time series of sedimentological variables: palaeotemperature, determined on the basis of the ratio of oxygen isotopes ${ }^{18} \mathrm{O} /{ }^{16} \mathrm{O}$, and organic substance deposited in Polish lakes.

The forecasts of the monthly and seasonal averages of air temperature in Warsaw in the $21^{\text {st }}$ century are shown as the diagrams of temporal trends $T=f(t)$ in Figs. 1 through 6 . These trends are the effect of the interference of the air temperature cycles proper for the winter (XII, I, II, XII-II), spring (III, IV, V, III-V), summer (VI, VII, VIII, VI-VIII), and autumn (IX, X, XI, IX-XI) months and seasons, determined on the basis of data for the years 1779-1990.

Temporal trends are the deterministic components of the measurement series. In essence, they serve for interpolation (within the interval) and extrapolation (beyond the bounds of the approximation interval) of the respective values. They define the general tendency of changes in climate (secular minima and maxima), and allow for the reconstruction of climate and for its forecasting. In view of the presence of random components in the expression for temperature, $T_{i}=f\left(t_{i}\right)+\varepsilon_{i}$, in the form of the rest $\varepsilon_{i}$, concrete values cannot be forecasted for even just one year ahead. 
According to the theory of statistical inference the hypothetical trend (in a population) is contained within the bounds of $f(t) \pm 1.96 \sigma$ with probability $95 \%$, since the rests $\varepsilon_{i}$ are distributed normally with parameters $0, \sigma$ (in this case standard errors $\sigma$ are close to the standard error).

Thus, the most frosty winters, with the average temperatures of $-7^{\circ} \mathrm{C}$ will most probably occur in the middle of the next century, at around the year 2050. In accordance with the resultant of the summer cycles of air temperature, cool summers will take place in the first two decades of the next century.

The existence of the real (deterministic) periods of air temperature, that is - the correctness of the statistical models - is confirmed by the verifiability of forecasts of climate changes in the $20^{\text {th }}$ century. Thus, the forecasts of air temperature trends in Warsaw elaborated for the period 1980-1995 on the basis of data from the years 1779-1979, presented in Boryczka (1993), proved to be correct. The secular minimum of temperature, forecasted for the year 1980 , took place in fact in 1980. The average annual temperature of $6.6^{\circ} \mathrm{C}$, noted in 1980 in accordance with the measurements from WarsawOkęcie weather station, is the lowest value in the 30-year period 1966-1996.

\section{REFERENCES}

Boryczka J., 1993, Naturalne $i$ antropogeniczne zmiany klimatu Ziemi $w$ XVII-XXI wieku [Natural and Anthropogenic Changes of the Earth's Climate in $17^{\text {th }}-21^{\text {st }}$ Centuries], Wydawnictwa UW, Warszawa.

B ory czk a J., 1998, Zmiany klimatu Ziemi [Changes of the Earth's Climate], Dialog, Warszawa.

Boryczka J., Stopa-Boryczka M., Blażek E., Skrzypczuk J., 1998, Atlas wspótzależności parametrów meteorologicznych i geograficznych $w$ Polsce. $C z . X I$ : Tendencje wiekowe klimatu miast $w$ Europie [Atlas of Co-dependences of the Meteorological and Geographical Parameters in Poland. Part XI: Secular Trends of Climate Changes in Towns of Europe], Wydawnictwa UW, Warszawa.

Boryczka J., Stopa-Boryczka M., Błazek E., Skrzypczuk J., 1999a, Atlas wspótzależności parametrów meteorologicznych i geograficznych $w$ Polsce. Cz. XII: Ocieplenia $i$ ochtodzenia klimatu miast $w$ Europie [Atlas of Co-dependences of the Meteorological and Geographical Parameters in Poland. Part XII: Warmings and Coolings of Climate of the Towns in Europe], Wydawnictwa UW, Warszawa.

Boryczka J., St opa-Boryczka M., Błażek E., Skrzy pczuk J., 1999b, Atlas wspótzależności parametrów meteorologicznych igeograficznych w Polsce. Cz. XIII: Cykliczne zmiany klimatu miast $w$ Europie [Atlas of Co-dependences of the Meteorological and Geographical Parameters in Poland. Part XIII: Cyclical Changes of Climate of the Towns in Europe], Wydawnictwa UW, Warszawa.

J on es P.D., J on s s on T., Wh e el er D., 1997, Extensions to the North Atlantic Oscillation Using Early Instrumental Pressure Observations from Gibraltar and South-West Iceland, Int. J. Climat., 17, 1433-1450.

Ż mudzka E., 1988, Cykliczne zmiany temperatury powietrza w Polsce [Cyclical changes of air temperature in Poland], Ph.D. dissertation, typescript, University of Warsaw, Warszawa. 
